\title{
Awareness and attitudes toward corneal donation among applicants and staff of a driver, vehicle and licensing authority (DVLA) in Ghana
}

Seth Lartey ${ }^{1,2,3}$, Ellen K. Antwi-Adjei ${ }^{2^{*}}$ (D), Solomon Agyapong², Abdul-Kabir Mohammed², Derrick N. O. Mensah ${ }^{2}$ and Edward S. Genego ${ }^{2}$

\begin{abstract}
Background: Corneal transplantations are surgeries performed for irreparable corneal diseases and damage. However, there is a gap between the number of potential recipients and the number of donor corneas available. The main aim of the study was to determine the awareness and attitudes toward corneal donation among applicants and staff of DVLA, Kumasi-Ghana.

Methods: A descriptive cross-sectional study was conducted. One hundred participants were selected using convenient sampling method. A structured questionnaire was used to elicit responses from participants concerning awareness and attitudes toward corneal transplant.

Results: The mean \pm SD age of the participants was $32.05 \pm 11.48$ years and age range, 18-67 years. Males were $66 \%$ whilst females constituted $34 \%$. 32.7\% of the participants were aware of corneal donation. Majority of the participants were Christians (83.1\%) and Singles (63\%). Television was the source of information with the highest preponderance (49.4\%). $67.3 \%$ were willing to donate their corneas after death. $63.9 \%$ were willing to indicate their donor statuses on drivers' license form which had a significant association with willingness to donate cornea after death $\left(p<0.05, x_{x}^{2}=12.187\right)$.

Conclusion: There is a poor level of awareness (32.7\%) of transplant and donation amongst the study population but a good level of willingness to donate organs (67\%). Consent via driving license would seem to be a good potential mode of obtaining consent to supplement the harvesting of adequate tissues for transplant if adequate awareness is created.
\end{abstract}

Keywords: Knowledge, Willingness, Unwillingness, Cornea, DVLA

\section{Background}

Corneal transplantation involves the removal of a diseased or damage cornea and replacing it with a healthy donated cornea. However, one of the major barriers to corneal transplantation is low consent rate and unavailability of donors inducing a huge gap

\footnotetext{
* Correspondence: antwi-adjeiellenkonadu@knust.edu.gh; ellennaky@yahoo.com

${ }^{2}$ Department of Optometry and Visual Sciences, Faculty of Biosciences, College of Science Kwame Nkrumah University of Science and Technology, Kumasi, Ghana

Full list of author information is available at the end of the article
}

between the number of potential recipients and the number of donors available $[1,2]$.

Even though corneal transplantation is the most common type of transplant surgery worldwide, in many subSaharan African countries where the need is greatest, transplant services are not available [3].

Factors that affect unwillingness to donate include age, educational level, knowledge about donation, religious beliefs, associated health problems, objection from family members whilst factors that favor donation are the desire to help others and gender $[4,5]$.

(c) The Author(s). 2019 Open Access This article is distributed under the terms of the Creative Commons Attribution 4.0 International License (http://creativecommons.org/licenses/by/4.0/), which permits unrestricted use, distribution, and 
There is limited literature on the knowledge and awareness level of Ghanaians about corneal transplantation. In Ghana corneal transplant is not routinely performed as there are no corneal banks available. Also, currently there is no legislature in Ghana regulating organ and tissue donation. It is unknown which type of organ donation system would work best in our environment. This makes it difficult to plan the best kind of National Cornea Donation program to adopt for a corneal transplant service.

The aim of this study was to determine awareness and attitudes towards corneal transplants among applicants and staff of DVLA and to also determine willingness to indicate their donor statuses on drivers' license forms. This information would help in the planning and determination of the best donation systems to adopt.

\section{Methods}

The study was a descriptive cross-sectional survey of drivers' license applicants and staff of DVLA, Kumasi, Ghana. Hundred participants with age $\geq 18$ years were recruited using convenience sampling method.

Data on demographics, socioeconomic status, knowledge corneal transplants, willingness to donate corneal after death, willingness to indicate donor status on drivers were collected using a structured questionnaire. Statistical Package for Social Sciences v22.0 was used for the analysis. $P$-values were obtained for the significant associations $(p<0.05)$. Chi- Square was used to assess associations between categorical variables.

\section{Results}

\section{Socio-demographic characteristics}

The study population consisted of 100 participants with mean age, $32.05 \pm 11.48$ years and age range, 1867 years. Out of the sample, $66 \%$ were males and $34 \%$ were females. The ages of males ranged from 20 to 67 years with mean $\pm(\mathrm{SD}), 33.98 \pm 12.47$ years and that of females ranged from 18 to 54 years with mean \pm ( SD) age, $28.29 \pm 8.19$ years (Table 1 ).

\section{Sources of knowledge of transplant}

Television was the main source of knowledge (49.4\%) and Newspaper the least (20.2\%) (Fig. 1).

\section{Knowledge and awareness of corneal donation for transplantation}

Out of the 100 participants, 98\% responded to the awareness of corneal transplant section out of which $32.7 \%$ of the respondents were aware of it.
Table 1 Distribution of socio-demographic characteristics $(N=$ 100)

\begin{tabular}{|c|c|c|}
\hline Variable & Freq & $(\%)$ \\
\hline \multicolumn{3}{|l|}{$\begin{array}{l}\text { Gender } \\
(N=100)\end{array}$} \\
\hline Male & 66 & 66 \\
\hline Female & 44 & 44 \\
\hline \multicolumn{3}{|l|}{$\begin{array}{l}\text { Age-Range/yrs. } \\
(N=100)\end{array}$} \\
\hline$\leq 20$ & 3 & 3 \\
\hline $21-30$ & 60 & 60 \\
\hline $31-40$ & 20 & 20 \\
\hline $41-50$ & 7 & 7 \\
\hline $51-60$ & 7 & 7 \\
\hline$\geq 60$ & 3 & 3 \\
\hline \multicolumn{3}{|l|}{$\begin{array}{l}\text { Marital Status } \\
(N=100)\end{array}$} \\
\hline Single & 63 & 63 \\
\hline Married & 32 & 32 \\
\hline Divorced & 2 & 2 \\
\hline Widowed & 3 & 3 \\
\hline \multicolumn{3}{|l|}{ Religion $(N=98)$} \\
\hline Christian & 82 & 83.7 \\
\hline Muslim & 15 & 15.3 \\
\hline Traditionalist & 1 & 1 \\
\hline \multicolumn{3}{|l|}{$\begin{array}{l}\text { Educational } \\
\text { Level }(N=100)\end{array}$} \\
\hline No Formal Education & 3 & 3 \\
\hline Elementary & 6 & 6 \\
\hline Junior High & 12 & 12 \\
\hline Senior High & 12 & 12 \\
\hline Vocational/ Commercial & 5 & 5 \\
\hline Training & 9 & 9 \\
\hline Polytechnic & 9 & 9 \\
\hline University & 44 & 44 \\
\hline \multicolumn{3}{|l|}{$\begin{array}{l}\text { Residence } \\
(N=96)\end{array}$} \\
\hline Rural & 27 & 28.1 \\
\hline Urban & 69 & 71.9 \\
\hline
\end{tabular}

$N$ Number of participants, Freq Frequency of participants, \% Percentage of participants, Variable-socio-demographic characteristic

$52.94 \%$ of the female respondents knew about corneal transplant against $21.88 \%$ of males with a statistically significant association $\left(p=0.002,{ }_{x}{ }^{2}=9.745\right)$

There was statistically significant association between awareness of corneal transplant and Ethnicity $(p=0.018$, $\left.x_{x}^{2}=14.822\right)$ and level of education $\left(p=0.001, x_{x}^{2}=26.029\right)$. The association between knowledge of corneal transplant and occupation was strong $\left(p=0.000,{ }_{x}^{2}=24.254\right)$ (Table 2 . 


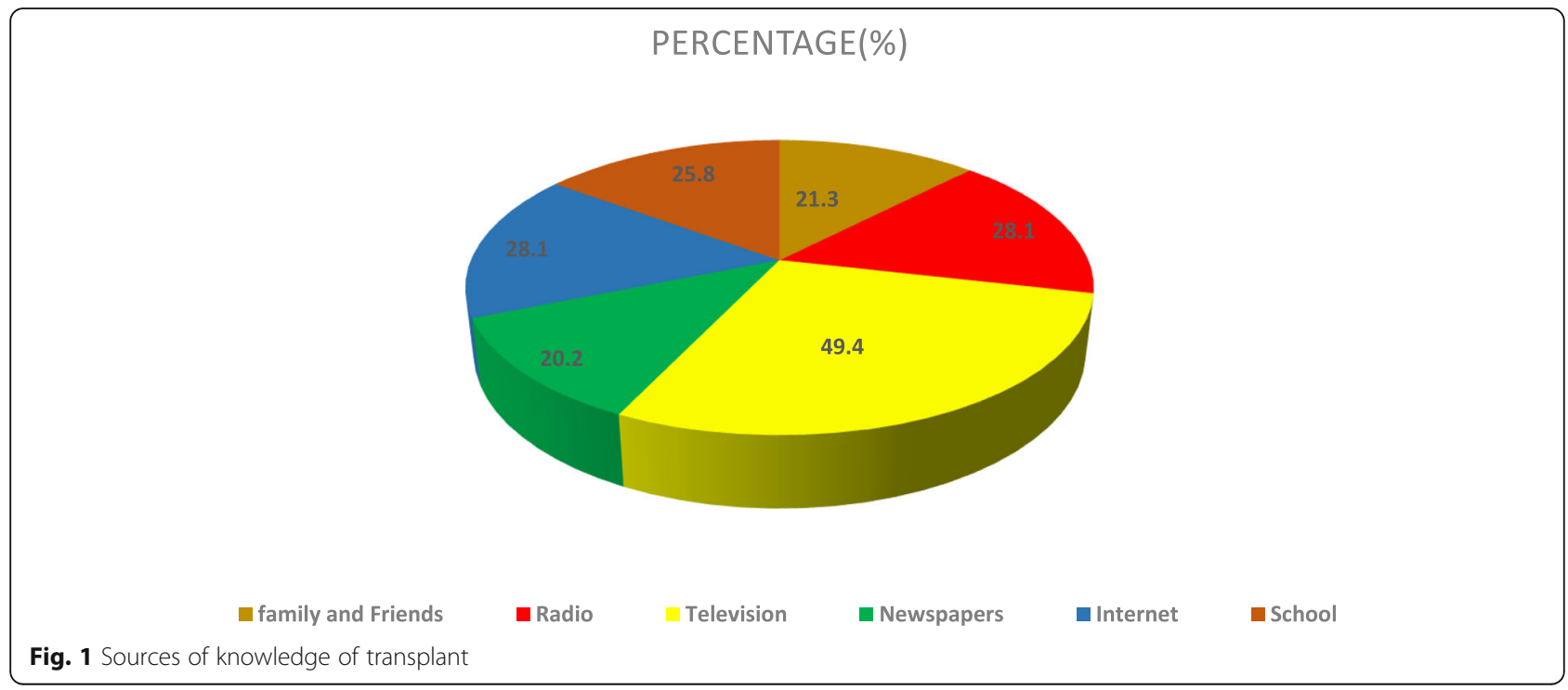

\section{Attitudes toward corneal donation}

Out of the respondents to willingness to donate eyes (cornea) section, 67.3\% were willing to donate their corneas after death.Age range was a relevant predictor of willingness to donate cornea after death $(p=0.043)$ with the age-range ( $\leq 20$ years, 51-60 years and $\geq 60$ years) with highest willingness to donate (Fig. 2).All the 32 participants who were aware of corneal transplant answered questions on corneal donation. Out of the respondents, $28(87.5 \%)$ reported that corneal donation is done surgically whereas $1(3.1 \%)$ indicated that it is done medically (using drugs) and $3(9.4 \%)$ reported that it can either be done surgically or medically (Table 3 ).

$26 \%$ of the study participants answered the part that asked about reasons for not donating. Out of the respondents, $7.7 \%$ reported that, it was against their religious belief, $11.5 \%$ indicated their families were not in support, $26 \%$ did not have any reason and $43.2 \%$ did not have much knowledge about organ or corneal donation. On the reason for donating, $67.1 \%$ reported it was out of love for humanity; $20 \%$ indicated it was their religious obligation; 51.4 opined they were donating to give others the chance for a better life whilst $14.3 \%$ indicated they will only donate if they will take money (Table 4).

Participant indicated their reservations about donations in Ghana (multiple responses).The majority (50.5\%) indicated that they do not have much information about donation. Most of the respondents (36.6\%) also indicated they do not trust the Ghana health system and $18.3 \%$ reported that their families will not agree.Less than $50 \%$ of the respondents knew that one can donate his organ when alive or dead (Table 5).

\section{Willingness to indicate donor status on drivers' license} form

$97 \%$ of the sample stated whether they were willing to indicate their donor statuses when going for drivers' license. Out of the respondents, $63.9 \%$ of them were willing to indicate their donor statuses on the Drivers' License form when going for them. There was statistically significant association between willingness to indicate Donor status on Drivers' $\mathrm{Li}$ cense form and willingness to willingness to donate cornea after death $\left(p=0.000,{ }_{x}^{2}=12.187\right)$ (Table 6).

\section{Discussion}

Awareness level of corneal transplant among the respondents in this study was low (32.7\%). A similar result was found in Medina, Saudi Arabia where 35.8\% of the study population were aware of corneal transplant [6] This contrast very much with Edwin and Raja (2000) who reported awareness regarding transplantation of eye, $88 \%$ [7]. It is also lower than the research by Vijayhhmahantesh et al. where $95.6 \%$ out of the 1052 participants knew about corneal transplant [8] perhaps because corneal transplant is routinely performed in that country, people have become more aware.

Out of the respondents, $67.3 \%$ were willing to donate their corneas after death. A relatively lower rate of donation was found in a study conducted in Saudi Arabia where $21.1 \%$ were willing to donate their eyes [6]. Willingness to donate cornea had a significant association with age range $\left(p=0.043, x^{2}=11.486\right)$. Old and very young people are more willing to donate than the mid-aged people.

The majority of the participants wanted to donate mainly because of altruistic and religious values; $67.1 \%$ reported that 
Table 2 Association between knowledge of Transplant and Socio-demographic characteristics

\begin{tabular}{|c|c|c|c|}
\hline \multirow[t]{2}{*}{ Variable } & \multicolumn{3}{|c|}{ Knowledge of corneal transplant } \\
\hline & Freq(\%) & $x^{2}$ & P-Value \\
\hline \multicolumn{4}{|l|}{ Gender } \\
\hline Male & $14(21.88)$ & 9.745 & $0.002^{*}$ \\
\hline Female & $16(52.94)$ & & \\
\hline \multicolumn{4}{|l|}{ Ethnicity } \\
\hline Akans & $17(26.98)$ & & \\
\hline Ga/ Adangme & $6(75)$ & & \\
\hline Ewe & $3(37.50)$ & 15.294 & $0.018^{*}$ \\
\hline Guans & $0(0)$ & & \\
\hline Nzema & $0(0)$ & & \\
\hline Other & $6(60)$ & & \\
\hline \multicolumn{4}{|l|}{ Educational Level } \\
\hline No formal Education & $0(0)$ & & \\
\hline Elementary & $1(20)$ & & \\
\hline Junior High & $0(0)$ & 25.151 & $0.001^{*}$ \\
\hline Senior High & $0(0)$ & & \\
\hline Vocational & $2(40)$ & & \\
\hline Training & $4(44.44)$ & & \\
\hline Polytechnic & $1(11.11)$ & & \\
\hline University & $24(54.54)$ & & \\
\hline \multicolumn{4}{|l|}{ Residence } \\
\hline Rural & $6(23.08)$ & 1.925 & 0.165 \\
\hline Urban & $26(38.24)$ & & \\
\hline \multicolumn{4}{|l|}{ Marital Status } \\
\hline Single & $25(39.68)$ & 5.000 & 0.172 \\
\hline Married & $6(20.69)$ & & \\
\hline Divorced & $1(50)$ & & \\
\hline Widowed & $0(0)$ & & \\
\hline \multicolumn{4}{|l|}{ Age-Range (years) } \\
\hline$\leq 20$ & $1(33.33)$ & 4.938 & 0.424 \\
\hline $21-30$ & $24(40)$ & & \\
\hline $31-40$ & $5(26.31)$ & & \\
\hline $41-50$ & $1(14.29)$ & & \\
\hline $51-60$ & $1(14.29)$ & & \\
\hline$\geq 60$ & $0(0)$ & & \\
\hline \multicolumn{4}{|l|}{ Religion } \\
\hline Christian & $26(32.10)$ & 2.061 & 0.357 \\
\hline Muslim & $5(25)$ & & \\
\hline Traditionalist & $1(100)$ & & \\
\hline
\end{tabular}

${ }^{*}$ significant at $p<0.05,{ }_{x}^{2}$ Chi-square value, Freq Frequency,Variable-socio demographic characteristics, \% 01Percentage

they will donate because of love for humanity, 20\% opined that it was their religious obligation, $51.4 \%$ reported they will donate to give others the chance for a better life.
Less than $50 \%$ which is $44.9 \%$ out of the respondents knew that a body can be donated whilst alive or dead which is lower than the $53.1 \%$ reported by Sandeep et al., (2017) [9].

Out of the people who knew about corneal transplant, $37.5 \%$ knew that corneal donation is done by giving part (cornea) of the eye to others with diseased part (cornea). The results indicated that even the few people who had heard about cornea transplant did not know much about the procedure itself.

$31.3 \%$ reported that anyone can donate his eyes. This show the lack of accurate knowledge of the procedure. $37.5 \%$ of the respondents reported that victims of every death qualify for eye donation provided the cornea is healthy.

These low rates of accurate knowledge given about the procedure by the respondents, indicates the need for awareness creation about cornea transplant.

This study revealed that $50.5 \%$ of the respondents did not have enough information about organ donation;18.6\% did not like the thought of people taking away their body parts; $19.6 \%$ believed their bodies would be grossly disfigured when their body parts are taken out; $14.4 \%$ wanted all their body parts to be intact during the funerals; $13.4 \%$ reported that it was against their religious beliefs; $11 \%$ opined it was a taboo in their culture and $11 \%$ were not comfortable discussing the topic and did not want to discuss it. Most respondents were concerned about the state of their bodies after death because of the common belief amongst Africans that one must return to the ancestral world with a complete body in order to have a peaceful rest otherwise the person's spirit will warn and haunt the living for vengeance. A similar study conducted by Pike et al. (1993) revealed that what prevented majority of the people from donating was lack of knowledge about organ transplantation which correlates with our findings [10]. A study in Pakistan had similar reasons where participants reported that "the body belongs to God and God gave it to man and no man can give it to another person" [11].

Out of the respondents, $63.9 \%$ were willing to indicate their donor status on drivers' license form. There was a significant association between willingness to indicate donor status on drivers' License form and willingness to donate eye $\left({ }_{x}^{2}=12.187, p<0.05\right)$.

\section{Limitation of the study}

This study was carried out at only one DVLA Centre.

\section{Conclusion}

This study has revealed low level of awareness of cornea transplant among participants (32.7\%). More than 


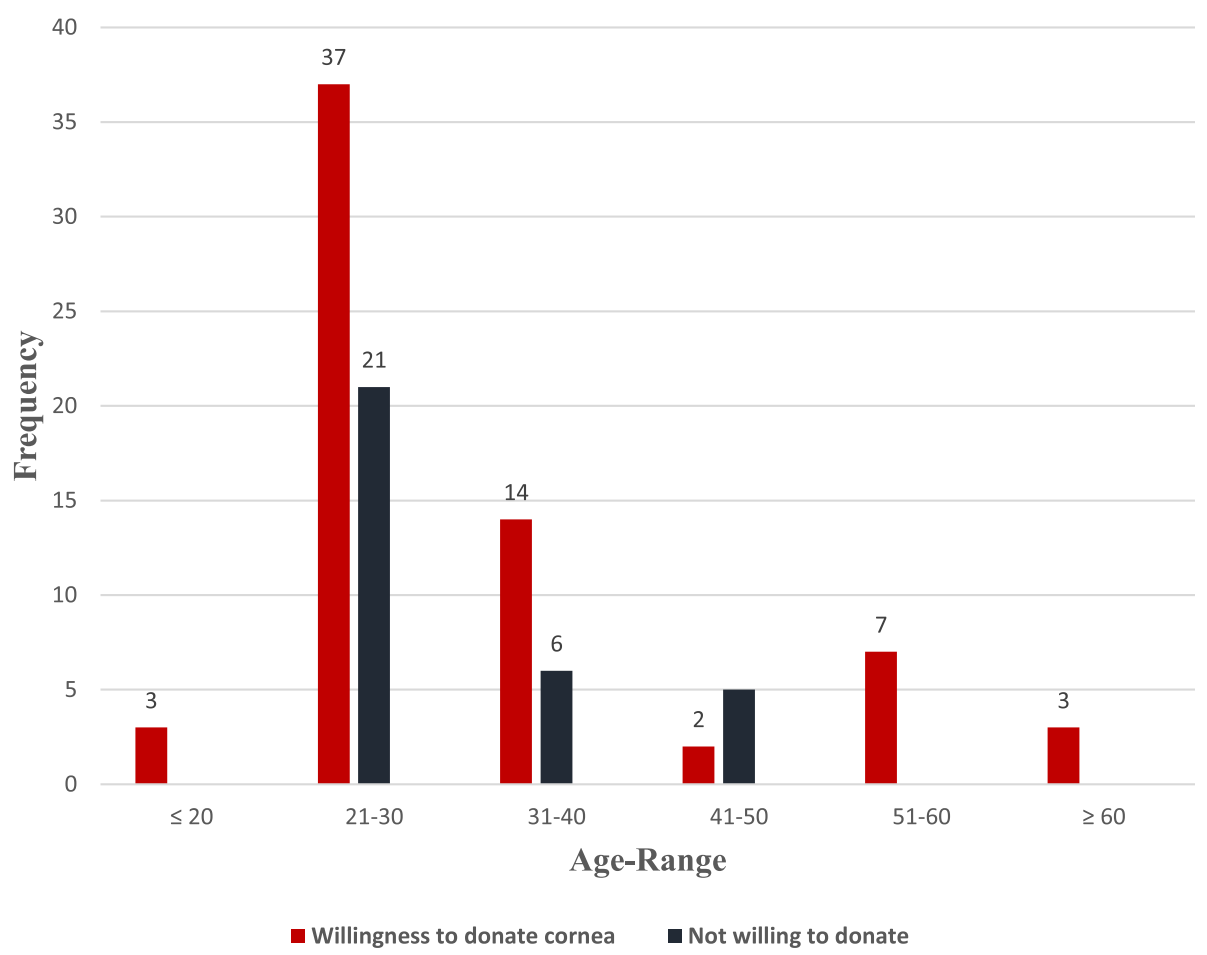

Fig. 2 Willingness and Unwillingness to donate cornea after death mateched with Age-range

Table 3 Knowledge of Corneal Donation

\begin{tabular}{ll}
\hline Knowledge of Eye Donation & $\begin{array}{l}\text { Freq } \\
(\%)\end{array}$ \\
\hline Knowledge of Eye Donation ( $N=32)$ & $1(3.1)$ \\
It is giving the whole eye to someone with diseased eye & 12 \\
It is giving part of the eye (cornea) to others with diseased & $(37.5)$ \\
eye & 16 \\
It can be done to replace either part or whole eye & $(50.0)$ \\
& $3(9.4)$ \\
Do not know & \\
Who can donate his Eye?(N=32) & 10 \\
Anyone & $(31.3)$ \\
Only Adults & 18 \\
The aged & $(56.3)$ \\
Do not Know & $1(3.1)$ \\
Victims of which death can donate their eyes $(N=32)$ & $3(9.4)$ \\
Road Traffic accidents & \\
Death through Diseases & $7(21.9)$ \\
Death natural causes & $4(12.5)$ \\
All types of Death & $3(9.4)$ \\
Do not Know & 12 \\
& $(37.5)$ \\
Freq Fequency of & 6 \\
& $(18.50)$ \\
\hline
\end{tabular}

Freq Frequency of respondents, \% Percentage
Table 4 Reasons for Donating and Decision Making

\begin{tabular}{ll}
\hline Reasons for donating and Decision making & Freq(\%) \\
\hline $\begin{array}{l}\text { Reasons for Donating } \\
\text { Lultiple responses, } N=70)\end{array}$ \\
$\begin{array}{l}\text { Love for humanity } \\
\text { My Religious Obligation }\end{array}$ & $47(67.1)$ \\
Give others the chance & $14(20)$ \\
for a better life & $36(51.4)$ \\
If I will take money & $10(14.3)$ \\
Decision Making (Multiple responses) & \\
Myself (N=97) & $64(66)$ \\
Family (N=97) & $28(29.2)$ \\
Spouse (N=96) & $19(19.6)$ \\
Children ( $N=97)$ & $27(27.8)$ \\
Should You be paid for donating?(N=98) & \\
Yes & $29(30.2)$ \\
No & $67(69.8)$ \\
Should Your surviving family be paid?(N=94) & \\
Yes & $39(41.5)$ \\
No & $55(58.5)$ \\
\hline
\end{tabular}

$N$ Number of respondents, Freq Frequency of respondents, \% Percentage of respondents 
Table 5 Concerns and Reservations about Donation and Transplant in Ghana

\begin{tabular}{|c|c|}
\hline Concerns and Reservations of Donation & Freq (\%) \\
\hline \multicolumn{2}{|l|}{ Concerns of Donation (multiple responses) } \\
\hline $\begin{array}{l}\text { I do not have enough information } \\
\text { about organ donation }\end{array}$ & $49(50.5)$ \\
\hline $\begin{array}{l}\text { I do not like the thought of people } \\
\text { taking out my body parts }\end{array}$ & $18(18.6)$ \\
\hline $\begin{array}{l}\text { I think my body would be grossly } \\
\text { disfigured when taken out }\end{array}$ & 19 (19.6) \\
\hline $\begin{array}{l}\text { I want all my body parts to be intact } \\
\text { during my funeral }\end{array}$ & $14(14.4)$ \\
\hline It is against my religious belief & $13(13.4)$ \\
\hline It is a taboo in my culture & $11(11)$ \\
\hline $\begin{array}{l}\text { I am uncomfortable with this topic } \\
\text { and don't want to discuss it }\end{array}$ & $11(11)$ \\
\hline \multicolumn{2}{|l|}{ Reservations } \\
\hline I do not trust the Ghana Health system & $34(36.6)$ \\
\hline $\begin{array}{l}\text { I'm afraid my body parts would } \\
\text { be used for rituals }\end{array}$ & $7(7.5)$ \\
\hline $\begin{array}{l}\text { I'm afraid my body parts may be } \\
\text { sold for profit }\end{array}$ & $6(6.5)$ \\
\hline $\begin{array}{l}\text { I'm afraid Doctors may not do much } \\
\text { to my life when I'm sick because } \\
\text { they want my body parts }\end{array}$ & $6(6.5)$ \\
\hline My family will not agree & $17(18.3)$ \\
\hline I have no reservation & $22(23.7)$ \\
\hline \multicolumn{2}{|l|}{ When can one donate body parts? } \\
\hline Whilst Alive & $36(40.4)$ \\
\hline After Death & $7(7.9)$ \\
\hline Both & $40(44.9)$ \\
\hline Do not know & $6(6.7)$ \\
\hline \multicolumn{2}{|l|}{$\begin{array}{l}\text { Is Organ and Corneal Donation } \\
\text { Urgent in Ghana? }\end{array}$} \\
\hline Yes & $62(76.5)$ \\
\hline No & 19 (23.5) \\
\hline
\end{tabular}

Freq Frequency of respondents, \% Percentage of respondents, Reservations Reservations toward donation

half of the study population reported that they were willing to donate their organs and corneas (67\%.). The main reason for unwillingness to donate was lack of knowledge about donation to make the decision. More than half of the participants stated that they were willing to indicate on the Drivers' License form their donor status. There was a strong relationship

Table 6 Association between willingness to donate cornea and willingness to indicate donor status on drivers' license form

\begin{tabular}{lccc}
\hline Willingness & \multicolumn{3}{l}{ Willingness to indicate Donor Status on License Form } \\
\cline { 2 - 4 } to Donate & Freq $(\%)$ & $x^{2}$ & $P$-Value \\
\hline Cornea & $49(75.54)$ & 12.187 & $0.000^{*}$ \\
\hline${ }^{*}$ significant at $p<0.05$, Freq Frequency of respondents, ${ }^{2}$ Chi Square value
\end{tabular}

between willingness to indicate donor status on Drivers' license form and willingness to donate cornea. Consent via driving license would seem to be a good potential mode of obtaining a donor pool to supplement the harvesting of adequate tissues for transplant if adequate awareness is created.

\section{Abbreviations}

DVLA: Driver Vehicle and Licensing Authority; SD: Standard Deviation

\section{Acknowledgments}

Much appreciation goes to the Administration of DVLA, Kumasi for their assistance and for expediting the data collection process.

\section{Authors' contributions}

SL conceived the research ideas. SL, EKA-A, SA and A-KM contributed to the conception and the research design. SA, NODM and SEG participated in the writing, workflow and data collection. SL, EKA-A, SA, AKM, NODM and SEG participated in the interpretation of data and analysis while SA wrote the first draft. SL and EKA-A reviewed the first draft and offered substantial revisions which was incorporated into the subsequent and final drafts. All authors read and approved the final manuscript as submitted and take full responsibility for the manuscript

\section{Funding}

Not applicable.

\section{Availability of data and materials}

The datasets used and analysed during the current study are available from the corresponding author on reasonable request.

\section{Ethics approval and consent to participate}

The study was approved by the Committee on Human Research, Publication and Ethics (CHRPE), School of Medical Sciences Kwame Nkrumah University of Science and Technology (KNUST)/ Komfo Anokye Teaching Hospital. Written consents were obtained from each participant.

\section{Consent for publication}

Not applicable.

\section{Competing interests}

The authors declare that they have no competing interests.

\section{Author details}

'Department of Eye, Ear, Nose and Throat. School of Medical Science. College of Health Sciences, KNUST, Kumasi, Ghana. ${ }^{2}$ Department of Optometry and Visual Sciences, Faculty of Biosciences, College of Science Kwame Nkrumah University of Science and Technology, Kumasi, Ghana. ${ }^{3}$ Consultant ophthalmic surgeon, Komfo Anokye Teaching Hospital, Kumasi, Ghana.

Received: 5 December 2018 Accepted: 30 October 2019

Published online: 12 November 2019

\section{References}

1. Siminoff $L A$, Gordon N, Hewlett J, et al. Factors influencing families consent for donation of solid organs of solid organs for transplantation. JAMA. 2001; 286(1):71-7.

2. Bell M. Non-heart beating organ donation: old procurement strategy-new ethical problems. J Med Ethics. 2003;29:176-81.

3. Armitage WJ, Tullo AB, Larkin DF. The first successful full-thickness corneal transplant: a commentary on Eduard Zirm's landmark paper of 1906. Br J Ophthamol. 2006;90(10):1222-3.

4. Banyubala DN. Death in Ghana; sociocultural implications for organ transplant regulation. Med Int. 2014;14:52-79.

5. Thornton JD, Kristine A, Wong CV, Randall JC, Spigner C, et al. Ethnic and gender differences in willingness to donate among high school students to donate their organs. J Adolesc Health. 2006;39:266-74. 
6. Nojood H, Esraa J. Knowledge and attitude regarding eye donation and corneal transplantation among medical students of Taibash University of Medina, Saudi Arabia. International Journal of Academic Scientific Research. 2015;3(4):18-26.

7. Edwin AR, Raja D. Attitudes of health care professionals towards organ donation. Indian J Urol. 2000;16:98-105.

8. Vijayamahhantesh MB, Vallabha K. Knowledge, attitude and practice patterns regarding eye donations, eye banking and corneal transplant in tertiary care hospital. JKIMSU. 2015;4:4.

9. Sandeep S, Anika S, Nidhi D. Knowledge, Attitude, and Practices regarding organ donation among adult visitors in a public hospital in Delhi, India. Indian J Transportation. 2017;11(3):127-132.

10. Pike RE, Odell JA, Khan D. Public attitudes towards organ Donation in South Africa. S Afr Med J. 1993;83:91-4.

11. Farhat M, Aamir MJ, Bushira S. To donate kidney: public persepective from Pakistan. Bioethic. 2012;2012:2(2).

\section{Publisher's Note}

Springer Nature remains neutral with regard to jurisdictional claims in published maps and institutional affiliations.

Ready to submit your research? Choose BMC and benefit from:

- fast, convenient online submission

- thorough peer review by experienced researchers in your field

- rapid publication on acceptance

- support for research data, including large and complex data types

- gold Open Access which fosters wider collaboration and increased citations

- maximum visibility for your research: over $100 \mathrm{M}$ website views per year

At BMC, research is always in progress.

Learn more biomedcentral.com/submissions 